\title{
Estradiol Receptor (ER) Chromatin Immunoprecipitation in MCF-7 Cells
}

Pia Giovannelli*, Gabriella Castoria and Antimo Migliaccio

Department of Biochemistry, Biophysics and General Pathology, Second University of Naples, Naples, Italy

*For correspondence: pia.giovannelli@unina2.it

[Abstract] Steroid hormone receptors, for example estradiol receptor, act like transcription factors. In the cell, steroids bind to a specific receptor. Upon ligand binding, many steroid receptors dimerize and enter nuclei where they bind specific DNA sequences called Hormone Responsive Elements (HRE) and regulate gene transcription. ER is able to bind DNA sites that are not Estrogen Responsive Elements (ERE) so regulating also the transcription of genes that are not classically controlled by estrogens.

\section{Materials and Reagents}

1. Fetal bovine serum (FBS) (Life Technologies, Gibco ${ }^{\circledR}$, catalog number: 10270)

2. $200 \mathrm{mM} \mathrm{L-Glutamine} \mathrm{(100x)} \mathrm{(Life} \mathrm{Technologies,} \mathrm{Gibco}{ }^{\circledR}$, catalog number: 25030)

3. Penicillin-Streptomycin (100x) (Life Technologies, Gibco ${ }^{\circledR}$, catalog number: 15140-122)

4. Hydrocortisone (Sigma-Aldrich, catalog number: $\mathrm{H}-0888$ )

5. Insulin (Human, recombinant) (F. Hoffmann-La Roche, catalog number: 11376497001)

6. Estradiol (Beta-estradiol) (Sigma-Aldrich, catalog number: E8875)

7. Protease inhibitors cocktail tablets (LAP tablets) (F. Hoffmann-La Roche, catalog number: 11836153001)

8. Protein A-agarose fast flow (Sigma-Aldrich, catalog number: P3476)

9. Formaldeyde (Sigma-Aldrich)

10. Salmon sperm DNA

11. DPBS (Sigma-Aldrich, catalog number: D5652)

12. Proteinase K (F. Hoffmann-La Roche, catalog number: 03115879001)

13. Qiagen PCR purification kit

14. Immunoprecipitating antibody (ER-alpha) (Sigma-Aldrich, catalog number: E1396)

15. Primers CCDN1 locus (-1039 to 770 bp): Fw (-1039) (AACAAAACCAATTAGGAACCTT), Rv (-770) (ATTTCCTTCATCTTGTCCTTCT)

16. Primers CCDN1 promoter (-235 to $-53 \mathrm{bp})$ : Fw (-235) (TATGAAAACCGGACTACAGG), and $\mathrm{Rv}(-53)$ (CTGTTGTTAAGCAAAGATCAAAG)

17. Charcoal dextran stripped serum (CSS) (see Recipes) 
18. Phenol Red-free Dulbecco's Modified Medium (DMEM with PR) (Life Technologies, Gibco ${ }^{\circledR}$, catalog number: 31885) (for MCF-7 cells) (see Recipes)

19. Phenol Red-free Dulbecco's Modified Medium (DMEM w/o PR) (Life Technologies, Gibco $^{\circledR}$, catalog number: 11880) supplemented with Charcoal (for MCF-7 cells) (see Recipes)

20. 50x LAP (Protease inhibitor cocktail) (see Recipes)

21. DTT solution (see Recipes)

22. Buffer I (see Recipes)

23. Buffer II (see Recipes)

24. Buffer III or cell lysis buffer (see Recipes)

25. Buffer IV (see Recipes)

26. TSE I buffer (see Recipes)

27. TSE II buffer (see Recipes)

28. TSE III buffer (see Recipes)

29. TE buffer (see Recipes)

30. Elution buffer (see Recipes)

31. PCR buffer (see Recipes)

\section{Equipment}

1. Sonicator (equipped with a $3 \mathrm{~mm}$ diameter tip) (Sonics \& Materials, model: Vibracell VC 130PB)

2. $100 \mathrm{~mm}$ dishes

3. Centrifuge (Eppendorf centrifuge, model: 5417R)

4. Shaker

5. PCR thermal cycler

\section{Procedure}

1. The MCF-7 cells are plated in $100 \mathrm{~mm}$ dishes approximately at $40-50 \%$ cell confluence in Phenol red Dulbecco's modified medium. After12-18 $\mathrm{h}$, the Red phenol medium is substituted with Phenol red-free Dulbecco's modified medium supplemented with CSS. Cells are maintained in this medium for 3 or 4 days ( $80 \%$ confluence in $100 \mathrm{~mm}$ dishes).

2. Stimulate the cells with $10 \mathrm{nM}$ estradiol for various times from 15 to $75 \mathrm{~min}$ (the maximal ER binding to chromatin is usually observed after 30-40 min of hormone treatment). Use un-stimulated cells as negative control.

3. After hormone stimulation, wash the cells twice with cold PBS $(5-10 \mathrm{ml})$. 
4. Cross-link the cells with $10 \mathrm{ml} 1 \%$ formaldehyde solution in PBS at room temperature for 10 min. Add the formaldehyde to PBS immediately prior to use.

5. Rinse cells twice with cold PBS $(5-10 \mathrm{ml})$.

6. Add $1 \mathrm{ml} \mathrm{DTT}$ solution and collect the cells in a $1.5 \mathrm{ml}$ tube using a cell scraper.

7. After collecting, incubate the cells for $15 \mathrm{~min}$ at $30^{\circ} \mathrm{C}$ and centrifuge for 4 or $5 \mathrm{~min}$ at 3,000 RCF.

8. Wash the pellet three times with $1 \mathrm{ml}$ PBS and after every wash centrifuge at 3,000 RCF for $3 \mathrm{~min}$.

9. Wash sequentially the pellet with $1 \mathrm{ml}$ Buffer I with 50x LAP, $1 \mathrm{ml}$ Buffer II with LAP.

10. Suspend the cellular pellet in $300 \mu \mathrm{l}$ Buffer III with 50x LAP and incubate 10 min on ice.

11. Sonicate three times at $30-40 \%$ amplitude and $0.4 \mathrm{~W}$ intensity for $35 \mathrm{sec}$ each to obtain 200 bp DNA fragments. During the sonication, keep the samples on ice.

12. To define amplitude, intensity and duration of sonication, you can use a sample of MCF-7 cells, sonicate at different intensity, amplitude and duration and after check the DNA fragment size running the sonicated DNA on an agarose gel. The right conditions will be those that will allow you to obtain a DNA smear with the center on around $200 \mathrm{bp}$.

13. Centrifuge the cellular lysates at $20,000 \mathrm{RCF}$ for $10 \mathrm{~min}$ at $4{ }^{\circ} \mathrm{C}$, collect the supernatants and dilute ten fold using the Buffer IV with 50x LAP. Store in a rack and keep at $4{ }^{\circ} \mathrm{C}$ for 3 or $4 \mathrm{~h}$ or overnight (O.N).

14. For preparing the protein A-agarose $(40 \mu \mathrm{l}$ of $50 \%$ for each sample), wash twice the required amount of resin with TE solution (ten fold the protein A-agarose volume). Collect the protein A-agarose by brief centrifugation. After the last wash, discard the TE solution and add fresh TE solution and salmon sperm DNA $(20 \mu \mathrm{l}$ TE solution and $2 \mu \mathrm{g}$ salmon sperm DNA for each sample). Keep on a rotating platform at $4{ }^{\circ} \mathrm{C}$ for 3 or $4 \mathrm{~h}$ or O.N.

15. Clear the samples at $20,000 \mathrm{RCF}$ for $10 \mathrm{sec}$. Store at $-80{ }^{\circ} \mathrm{C}$ or use immediately for immunoprecipitation and lysates. Save back $20 \%$ of the total supernatant as total input control and process with eluted IPs beginning with the cross-link reversal step.

16. Add the immunoprecipitating antibody ( $2 \mu \mathrm{lER}$-alpha) to the $0.7 \mathrm{ml}$ samples fraction in a new tube and precipitate for $6 \mathrm{~h}$ or overnight. For a negative control, incubate $0.7 \mathrm{ml}$ samples fraction with $1 \mu \mathrm{l}(2 \mu \mathrm{g})$ of rabbit lgG. Keep all the samples on a rotating platform at $4{ }^{\circ} \mathrm{C}$

17. Add $40 \mu \mathrm{l}$ of blocked protein A-agarose beads at $4{ }^{\circ} \mathrm{C}$ with rotation O.N. if you have incubated the samples with the antibody for $6 \mathrm{~h}$ or for 2-3 $\mathrm{h}$ if you have incubated the samples with the antibody O.N.

18. Pellet beads by centrifugation $(3,000 \times \mathrm{g})$ at $4{ }^{\circ} \mathrm{C}$ and wash for 10 min sequentially with 1 $\mathrm{ml}$ of TSE I, $1 \mathrm{ml}$ of TSE II and $500 \mu \mathrm{l}$ of TSE III. Wash three times with $1 \mathrm{ml}$ TE Buffer. 
19. Elute with $300 \mu \mathrm{l}$ of freshly prepared elution buffer. Prepare buffer fresh each time. Vortex briefly to mix and shake gently on the vortex shaker for $10 \mathrm{~min}$.

20. Centrifuge at $20,000 \mathrm{rpm}$ for $10 \mathrm{~min}$, transfer supernatants to clean tube and add $200 \mu \mathrm{l}$ elution buffer in $100 \mu \mathrm{l}$ of the frozen input control.

21. Reverse formaldehyde cross-linking by heating at $65^{\circ} \mathrm{C} O . \mathrm{N}$.

22. Add $18 \mu \mathrm{l} 1 \mathrm{M}$ Tris- $\mathrm{HCl}(\mathrm{pH}$ 6.5) $0.5 \mathrm{M}$ EDTA and $5 \mu \mathrm{g}$ Proteinase $\mathrm{K}$ to each sample and heat at $48^{\circ} \mathrm{C}$ for $90 \mathrm{~min}$.

23. Isolate DNA by using either the Qiagen PCR purification kit.

24. Another method for isolating DNA is the $1 x$ phenol/chloroform extraction, $1 x$ chloroform extraction, O.N. precipitation using 2.5 volumes absolute ethanol with $30 \mu$ potassium acetate $3 \mathrm{M} \mathrm{pH} 5.7$ and $5 \mu \mathrm{g}$ glycogen. Wash pellets twice with $500 \mu \mathrm{l} 70 \%$ ethanol and air dried.

25. Resuspend pellets in $35 \mu \mathrm{TE}$ with $0.1 \mathrm{mg} / \mathrm{ml}$ RNase A.

26. Perform the conventional PCR using $2 \mu$ DNA per reaction. For example, for CCDN1 locus (-1039 to $-770 \mathrm{bp}$ ) or for CCDN1 promoter (-235 to $-53 \mathrm{bp}$ ) PCR, use $20 \mu \mathrm{l} \mathrm{H}_{2} \mathrm{O}$ solution with $1.5 \mathrm{mM} \mathrm{MgCl} 2,0.2 \mathrm{mM}$ dNTP, $0.25 \mu \mathrm{M}$ PRIMER F, $0.25 \mu \mathrm{M}$ PRIMER R, 0.5 U/ $\mu \mathrm{l}$ TAQ Pol, $2 \mu \mathrm{l}$ DNA and $2 \mu \mathrm{l} \mathrm{PCR}$ buffer. Use 33-35 cycles of amplification (denaturation $96{ }^{\circ} \mathrm{C}$ for $20 \mathrm{sec}$, annealing $50{ }^{\circ} \mathrm{C}$ for $90 \mathrm{sec}$, elongation $69^{\circ} \mathrm{C}$ for $60 \mathrm{sec}$ ). Run in a $2 \%$ agarose gel in TBE $0.5 \%$.

\section{Recipes}

1. Charcoal dextran stripped serum

Dextran coated charcoal is used to strip steroid hormones from serum. Charcoal/dextran stripped serum is commercially available, but we prepare the serum as described in Migliaccio et al. (2011).

2. Phenol red-free Dulbecco's modified medium for MCF-7 cells (DMEM with PR)

$5 \%$ FBS

$2 \mathrm{mM}$ L-glutamine

$100 \mathrm{U} / \mathrm{ml}$ penicillin-streptomycin

$3.75 \mathrm{ng} / \mathrm{ml}$ Hydrocortisone

$6 \mathrm{ng} / \mathrm{ml}$ Insulin

3. Phenol red-free Dulbecco's modified medium supplemented with Charcoal for MCF-7 cells

(DMEM w/o PR)

$5 \%$ CSS

$2 \mathrm{mM}$ L-glutamine 
$100 \mathrm{U} / \mathrm{ml}$ penicillin-streptomycin

$3.75 \mathrm{ng} / \mathrm{ml}$ Hydrocortisone

$6 \mathrm{ng} / \mathrm{ml}$ Insulin

4. 50x LAP (Protease inhibitor cocktail)

Dissolve a tablet in $1 \mathrm{ml}$ distilled $\mathrm{H}_{2} \mathrm{O}$ and use 50x

5. DTT solution

$10 \mathrm{mM}$ DTT

$100 \mathrm{mM}$ Tris- $\mathrm{HCl}$

$\mathrm{pH} 9.5$

6. Buffer I

$0.25 \%$ Triton $\mathrm{X}-100$

$10 \mathrm{mM}$ EDTA

$0.5 \mathrm{mM}$ EGTA

$10 \mathrm{mM}$ Hepes

$\mathrm{pH} 6.5$

7. Buffer II

$200 \mathrm{mM} \mathrm{NaCl}$

1 mM EDTA

$0.5 \mathrm{mM}$ EGTA

$10 \mathrm{mM}$ Hepes

$\mathrm{pH} 6.5$

8. Buffer III or cell lysis buffer

$1 \%$ SDS

10 mM EDTA

$50 \mathrm{mM}$ Tris- $\mathrm{HCl}(\mathrm{pH} 8.1)$

$50 x$ protease inhibitor cocktail

9. Buffer IV

1\% Triton X-100

2 mM EDTA

$150 \mathrm{mM} \mathrm{NaCl}$

$20 \mathrm{mM}$ Tris- $\mathrm{HCl}(\mathrm{pH} 8.1)$

10. TSE I buffer

$0.1 \%$ SDS

1\% Triton X-100

2 mM EDTA

$20 \mathrm{mM}$ Tris- $\mathrm{HCl}(\mathrm{pH} 8.1)$

$150 \mathrm{mM} \mathrm{NaCl}$ 
11. TSE II buffer

$0.1 \%$ SDS

1\% Triton X-100

2 mM EDTA

$20 \mathrm{mM}$ Tris- $\mathrm{HCl}(\mathrm{pH} 8.1)$

$500 \mathrm{mM} \mathrm{NaCl}$

12. TSE III buffer

$0.25 \mathrm{M} \mathrm{LiCl}$

$1 \%$ NP40

1\% Sodium Deoxycholate

1 mM EDTA

$10 \mathrm{mM}$ Tris- $\mathrm{HCl}(\mathrm{pH} 8.1)$

13. TE buffer

$20 \mathrm{mM}$ Tris- $\mathrm{HCl}(\mathrm{pH} 8.1)$

1 mM EDTA (pH 8.0)

14. Elution buffer

$1 \%$ SDS

$0.1 \mathrm{M} \mathrm{NaHCO}_{3}$

15. PCR buffer

300 mM Tris-Base

$100 \mathrm{mM}$ Hepes

250 mM Potassium Chloride

200 mM Potassium Glutamate

$20 \mathrm{mM}$ DTT

$50 \%$ Glycerol

Sterilize by filtration

\section{Acknowledgments}

This work was funded by the Italian Association for Cancer Research (A.I.R.C.; Grant No. IG 5389). Pia Giovannelli is supported by a fellowship from A.I.R.C. This protocol was adapted from Castoria et al. (2012).

\section{References}

1. Castoria, G., Giovannelli, P., Lombardi, M., De Rosa, C., Giraldi, T., de Falco, A., Barone, M. V., Abbondanza, C., Migliaccio, A. and Auricchio, F. (2012). Tyrosine phosphorylation 
of estradiol receptor by Src regulates its hormone-dependent nuclear export and cell cycle progression in breast cancer cells. Oncogene 31(46): 4868-4877.

2. Lombardi, M., Castoria, G., Migliaccio, A., Barone, M. V., Di Stasio, R., Ciociola, A., Bottero, D., Yamaguchi, H., Appella, E. and Auricchio, F. (2008). Hormone-dependent nuclear export of estradiol receptor and DNA synthesis in breast cancer cells. J Cell Biol 182(2): 327-340.

3. Migliaccio, A., Castoria, G., Auricchio, F. (2011). Analysis of androgen receptor rapid actions in cellular signaling pathways: receptor/Src association. Methods Mol Biol 776: 361-370.

4. Yahata, T., Shao, W., Endoh, H., Hur, J., Coser, K. R., Sun, H., Ueda, Y., Kato, S., Isselbacher, K. J., Brown, M. and Shioda, T. (2001). Selective coactivation of estrogendependent transcription by CITED1 CBP/p300-binding protein. Genes Dev 15(19): 25982612. 